\title{
Research of Non-metallic Inclusions Removal in Teeming Ladles of Various Design
}

\author{
Molchanov L. S. ${ }^{1}$, Synehin Y. V..$^{*}$, Lantukh O. S. ${ }^{1}$, Ryshkova I. S. ${ }^{2}$ \\ ${ }^{1}$ National Metallurgical Academy of Ukraine, 4 Gagarina Av., 49600 Dnipro, Ukraine; \\ ${ }^{2}$ Dniprovsk State Technical University, 2 Dniprobudivska St., 51918 Kamianske, Ukraine
}

\section{Article info:}

Paper received:

The final version of the paper received:

Paper accepted online:
March 17, 2018

July 31,2018

August 4, 2018
*Corresponding Author's Address: sinegin.ev@gmail.com

\begin{abstract}
It was studied in the article the possibility of intensification of removal of non-metallic inclusions in a teeming ladle during holding without any additional external influences on the metal (argon blowing or electromagnetic stirring). Increasing the efficiency of removal of non-metallic inclusions is achieved by creating in a teeming ladle during tapping a circulation pattern that accelerate the floating of inclusions. The described effect is achieved by using a rational shape of the workspace of the teeming ladle, which has been found as a result of "water" modelling. To carry out the experiment, the authors have proposed the similarity numbers describing the floating of non-metallic inclusions in the ladle during the tapping and for some time after its completion. On the basis of the proposed similarity numbers, an experimental facility and the experimental method were developed. In the course of the experiment, the construction of linings of several types was studied. Ladles of the best design provide by 16-19\% faster removal of non-metallic inclusions from steel than in ladles of conventional design. The results of the research can be useful for mini-plants and enterprises with ladles of small capacity, where the use of argon blowing and electromagnetic stirring is technologically and economically unreasonable.
\end{abstract}

Keywords: "water" modelling, floating, non-metallic inclusions, damping devices.

\section{Introduction}

It is well known, that non-metallic inclusions (NI) in steel are not only concentrators of internal stresses, but also under certain conditions can cause corrosion destroying of steel [1]. The main sources of steel pollution by NI at the stage of tapping from BOF into the ladle are furnace slag, fragments of the ladle lining and products of deoxidation.

Usually NI are removed from steel by floating up due to the Archimedean force and the convection in liquid steel. At the same time for the small NI prevails the influence of convection, and for large - the Archimedean force [2]. Intensification of this process is carried out by accelerating upward flow of the melt by means of inert gas blowing or electromagnetic stirring. However, the application of these measures for teeming ladles of lowcapacity is inappropriate due to the significant thermal losses and the risk of getting the slag inclusions from the cover slag back into the metal with the injection of argon. Electromagnetic stirring requires significant capital expenditures for its implementation.
Therefore, the only technologically expedient way for NI removing from steel is to hold the metal melt in the ladle for optimal time.

\section{Literature Review}

Sang-Ik Chung et al. [3] were exploring the removal of NI during the processing of steel in ASEA-SKF. By using mathematical modeling and statistical analysis of industrial data they have determined that the removal of NI with the diameter of $10-100 \mu \mathrm{m}$ is the most effective under the condition of combined stirring of upward induction stirring of $400 \mathrm{~A}$ and gas blowing of $5 \mathrm{l} / \mathrm{min}$.

The similar research has been carried out by Lidong Teng [4] on stainless steel. He has determined that during Ar injection and simultaneous EMS inclusions with a size of more than $5.4 \mu \mathrm{m}$ after LF-EMS is reduced by $50 \%$ compared to that after argon gas stirring ladle station. Inclusions with a size of more than $5.4 \mu \mathrm{m}$ after LF-EMS is reduced by more than $70 \%$ compared to that after argon gas stirring. 


\section{Research Methodology}

\subsection{Formularization of similarity numbers}

Based on the results of the preparatory stage [5], the authors, using the $\pi$-theorem, established that the process of NI floating after filling the ladle can be described by the Archimedes number (Ar), the modified homochronality number $\left(\mathrm{Ho}_{\mathrm{m}}\right)$ and the linear simplex $(\mathrm{D})$ :

$$
\begin{gathered}
\mathrm{Ar}=\frac{\Delta \rho \cdot g \cdot d_{N I}^{3}}{\rho_{l i q} \cdot v_{l i q}^{2}} ; \\
\mathrm{Ho}_{\mathrm{m}}=\frac{g \cdot \tau^{2}}{h_{l i q}} ; \\
\mathrm{D}=\frac{d_{N I}}{h_{l i q}},
\end{gathered}
$$

where $\rho_{\text {liq }}, \Delta \rho$ - respectively the density of the liquid and the density difference of the liquid and NMI, $\mathrm{kg} / \mathrm{m}^{3}$; $g-$ acceleration of gravity, $\mathrm{m} / \mathrm{s}^{2} ; d_{N I}$ - diameter $\mathrm{HB}, \mathrm{m}$; $v_{l i q}$ - the kinematic viscosity of the liquid, $\mathrm{m}^{2} / \mathrm{s}$; $\tau$ - time, $\mathrm{s} ; h_{l i q}$ - the level of liquid in the ladle, $\mathrm{m}$.

However, calculating the scales of simulation, the authors have encountered the problem of choosing model substances that would satisfy the condition:

$$
\left\{\begin{array}{l}
\mathrm{Ar}=\text { idem } \\
\mathrm{Ho}_{\mathrm{m}}=\text { idem } \\
\mathrm{D}=\text { idem }
\end{array}\right.
$$

The material that imitates NI must have a spherical shape and also not dissolve and not form a conglomeration in water. Polyethylene and stearin good satisfy these requirements. However, the linear scale for these materials is 1.8. It means that the model of a ladle must be 1.8 times larger than the original. Using a smaller linear scale requires the application of a liquid with low density and/or viscosity instead of water.

According to Markov [6], in case of too incomparable linear parameters in a similarity number, it can be neglected as not essential. Based on this statement and considering the small value of the linear simplex $\mathrm{D}=10^{-6}-10^{-3}$, authors have put forward the hypothesis of self-similarity of the linear simplex D. It means that for simulation of the process it is need only to provide the value of linear simplex less than particular value.

\subsection{Methodology of "water" modeling}

For experimental confirmation of the hypothesis, an experimental facility was assembled and a series of 15 experiments was carried out. The experimental facility is shown in Figure 1.

The facility consisted of a set of ladle models 1 of different sizes. The necessity of use several models of different sizes is caused by the need to vary the magnitudes of the Archimedes number and the linear simplex within ranges of their definition independently of each other.
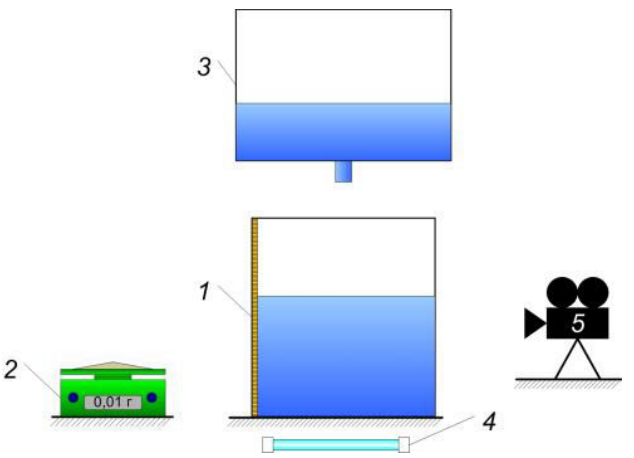

Figure 1 - The scheme of the experimental facility: 1 - model of the ladle; 2 - electronic scales; 3 - buffer vessel; 4 - halogen lamp; 5 - video camera

Before the experiment a charge of the stearin was weighed on an electronic scale 2 with an accuracy limit of $0.01 \mathrm{~g}$. The weight of the charge is based on the similarity of the volumetric concentration of powder in the liquid on the model and the original of $2.88 \cdot 10^{-3} \mathrm{~m}^{3} / \mathrm{m}^{3}$ [7]. The weighed powder sample was gently loaded onto the bottom of the ladle, after which water was poured from the buffer vessel 3. The height of the drain hole above the bottom of the ladle model was changed according to the linear scale for each experiment. From the bottom, the ladle was illuminated by a $150 \mathrm{~W}$ halogen lamp 4. The duration of floating was determined from the video of the experiments that were taking by the video camera 5 in the HD mode.

According to Markov [6], the self-similarity of a dimensionless number can be confirmed in following condition:

$$
\frac{d \lg \pi_{y}}{d \lg \pi_{x}}=0,
$$

where $\pi_{y}$ and $\pi_{x}$ - respectively the dimensionless function and its dimensionless argument.

Condition (5) is observed for $\lg D<-2(D<0.01)$. This means that to fulfil semblance of the floating NI during holding steel in the ladle the diameter of the NI must be at least 100 times smaller than the level of liquid steel in the ladle.

As a result of following statistical analysis it has been determined that the duration of NI floating can be calculated by using following equation:

$$
\mathrm{Ho}_{m}=42420 \mathrm{Ar}^{-0,51} \mathrm{D}^{-0,86}
$$

The results of equation (6) and Stocks equation are different. According Frolov [8] his difference might be caused by turbulence during simultaneous floating of large group of NI.

\subsection{Effect of lining design on duration of NI floating up}

On the next stage of research authors have varied the shape of model workspace in order to determine the optimal for decreasing of floating duration. The following shapes of model's bottom have been offered (Figure 2). 


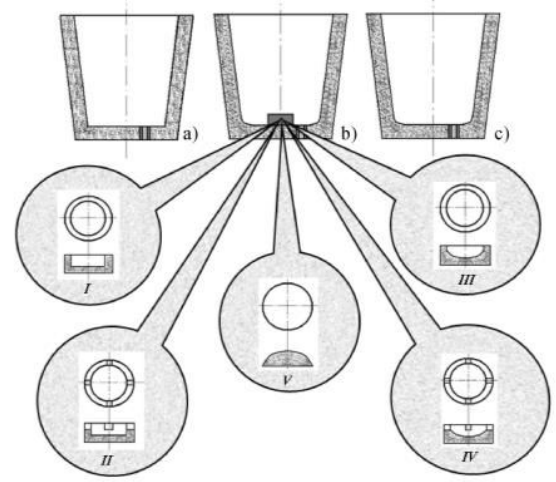

Figure 2 - Types of the shape of model workspace: $\mathrm{a}$ - common design of the ladle; $\mathrm{b}$ - ladle equipped with fillet and various damping device; $\mathrm{c}$ - ladle equipped with fillet

Type (a) is common design. Type (c) has fillet between ladle's bottom and wall with various rounding radius. Type (b) has besides fillet also damping device of various design in the place of steel jet impact. Offered measures have to provide change of flow pattern in ladle in a way to decrease duration of NI floating up.

The experiments were carried out on the model with linear scale 1:10 and using the stearin granules average size $750 \mu \mathrm{m}$. In condition of these experiments stearin granules simulate NI average size $320 \mu \mathrm{m}$.

The experiment on each type of the shape of model workspace was carried out three times. So for analysis average value of duration of NI floating up were taken.

\section{Results and Discussion}

Considering that a time scale is about 1:3 the results of experiment were converted for original teeming ladle of $60 \mathrm{t}$ capacity. Comparison of average duration of NI floating up for each type of the shape of model workspace is shown on Figure 3.

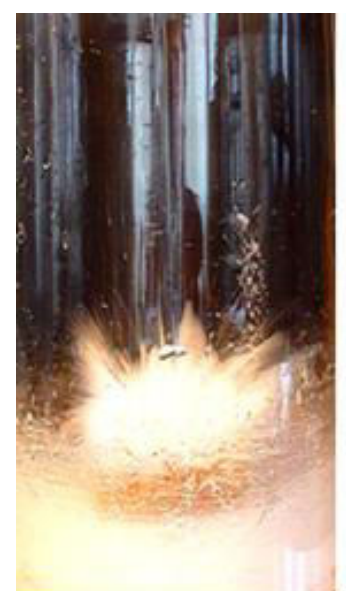

b I

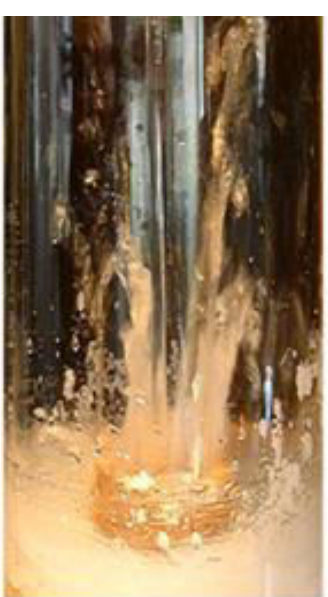

b II

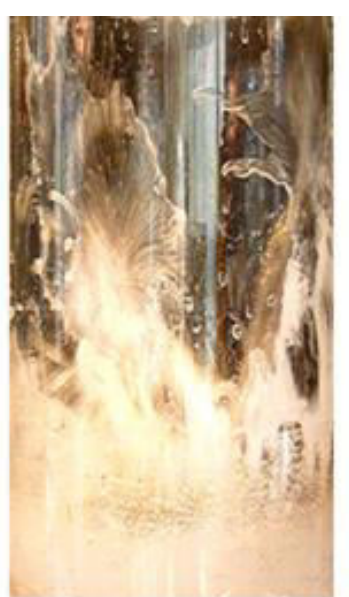

b III

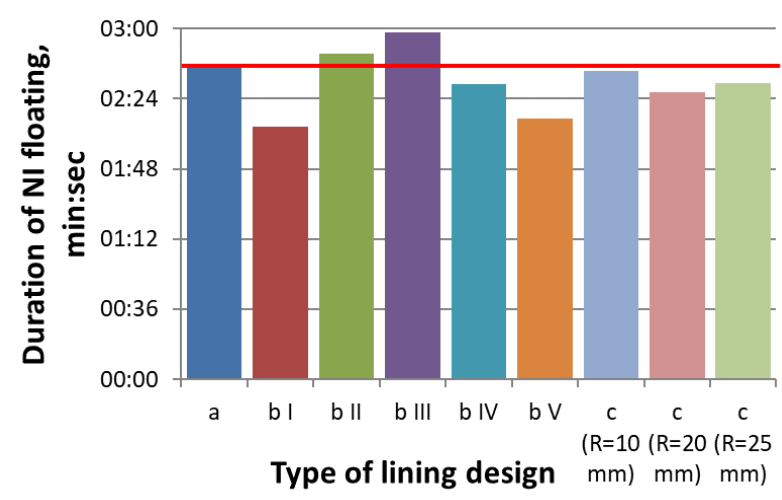

Figure 3 - Comparison of various types of the shape of model workspace

It is clearly seen that the best results were achieved with using damping device in form of hemisphere ("b V") and bowl ("b I"). Model equipped only with fillet has shown the worst result ("c").

Another important feature is the height of splash after impact of metal jet with the bottom of teeming ladle. The large splash leads to increase of metal surface that interacts with atmospheric oxygen. This causes to secondary oxidation of steel.

On the Figure 4 it was shown the splash after impact of metal jet with the bottom of teeming ladle of type " $b$ " design (Figure 2). The largest splashes can be seen at the ladles of types "b II, III, IV". The splashes in these cases reached almost to the edge of the ladle. For "b I" types the splash was quite small and almost as the same height as for the common ladle design. The shape of damping device in form of hemisphere ("b V", Figure 3) has provided no splash at all, only little turbulences at the fillet between ladle's bottom and wall.

Thus the "b V" type of the teeming ladle provides both most efficient of NI remove from steel and the lowest level of secondary oxidation during the tapping.

Figure 4 - Splash after impact of metal jet with the bottom of teeming ladle of various design

Obviously increase of efficiency of NI removal is a consequence of flow pattern which is induced during steel tapping. Increase of duration of NI floating up for some types of the shape of model workspace can be explained by creating in liquid dead zones that keep NI inside. 


\section{Conclusions}

Authors have proved that to fulfill semblance of the floating NI during holding steel in the ladle the diameter of the NI must be at least 100 times smaller than the level of liquid steel in the ladle. It makes possible to get accurate results in research of NI removal on "water" models.
By using "water" modeling, authors have found the shape of teeming ladle's workspace that change the flow pattern in ladle during the steel taping in a way to decrease duration of NI floating up.

The use of teeming ladle equipped with damping device in form of hemisphere and bowl provides decrease of duration of NI floating up by $16-19 \%$.

\title{
References
}

1. Filippov, G. A., Rodionova, P. G., \& Baklanova, O.N. (2004). Korrozionnaya stoykost stalnyih truboprovodov [Corrosion resistance of steel pipelines]. Tehnologiya metallov [Technology of metals], Vol. 2, pp. 24-27 [in Russian].

2. Okhotskyi, V. B., Kostolov, O. L., Cimonov, V. K., Kovalov, D. A., Tarakanov, A. K., Kucher, A. H., et al. (1997). Teoriia metalurhiinykh protsesiv [Theory of metallurgical processes]. Kyiv, IZMN [in Russian].

3. Chung, S.-I., Shin, Y.-H., Yoon, J.-K. (1992). Flow Characteristics by Induction and Gas Stirring in ASEA-SKF Ladle. ISIJ International, Vol. 32, Issue 12, pp. 1287-1296.

4. Teng, L. (2017). Effect of EMS on Inclusion Removal in Ladle Furnace for Specialty Steel Production. Proceedings of AISTech 2017, pp. 1395-1402.

5. Lantukh, O. S., Molchanov, L. S., \& Synehin, I. V. (2018). Metodyka fizychnoho modeliuvannia splyvannia ansambliu nemetalevykh vkliuchen u stalerozlyvnomu kovshi [Method of physical modeling of floating of the nonmetallic inclusions group in a teeming ladle]. Matematychne modeliuvannia [Mathematical modelling], Vol. 1 (38), pp. 95-99.

6. Markov, B. L. (1984). Fizicheskoe modelirovanie v metallurgii [Physical modeling in metallurgy]. Moscow, Metallurgy [in Russian].

7. National Metallurgical Academy of Ukraine (2017). Rozrobka teoretychnykh zasad enerho- ta resursozaoschadzhuiuchykh tekhnolohij vyplavky ta bezperervnoho rozlyvannia iakisnykh marok stalej [Development of theoretical foundations of energy and resource saving technologies of melting and continuous casting of qualitative grades of steels]. Dnipro, NMetAU, State registration No. $0116 \mathrm{U} 008351$ [in Ukrainian].

8. Frolov, J. G. (1988). Kurs kolloidnoj himii. Poverhnostnye javlenija i dispersnye sistemy [Course of colloid chemistry. Surface phenomena and dispersed systems]. Moscow, Chemistry [in Russian].

\author{
Дослідження процесу вилучення неметалевих включень \\ в сталерозливних ковшах різної конструкції \\ Молчанов Л. С. ${ }^{1}$, Синегін С. В. ${ }^{1}$, Лантух О. С. ${ }^{1}$, Ришкова I. С. ${ }^{2}$ \\ ${ }^{1}$ Національна металургійна академія України, просп. Гагаріна, 4, 49600, м. Дніпро, Україна; \\ 2 Дніпровський державний технічний університет, вул. Дніпробудівська, 2, 51918, м. Кам'янське, Україна
}

\begin{abstract}
Анотація. У статті досліджена можливість інтенсифікації видалення неметалевих включень у ковші без будь-якого додаткового зовнішнього впливу на метал (продування аргоном або електромагнітне перемішування). Підвищення ефективності видалення неметалевих включень досягається за рахунок створення циркуляції, що прискорює плавання включень. Описаний ефект досягається використанням раціональної форми робочого простору ковша, отириманої у результаті моделювання. Для проведення експериментальних досліджень авторами запропонувані критерії подібності, що описують плавучість неметалевих включень у ковші під час заливання і впродовж деякого часу після його завершення. На основі запропонованих критеріїв подібності розроблено відповідний експериментальний метод. Під час експеримента вивчено конструкцію декількох видів футеровок. Ковші найкращої конструкції забезпечують на 16-19 \% швидше вилучення неметалевих включень зі сталі, ніж у ковшах традиційної конструкції. Результати дослідження можуть бути корисними на малих підприємств, що використовують ковші малої потужності, де застосування технологій аргонного продування та електромагнітного перемішування $\epsilon$ економічно необгрунтованими.
\end{abstract}

Ключові слова: водне моделювання, плавання, неметалеве включення, демпферний пристрій. 